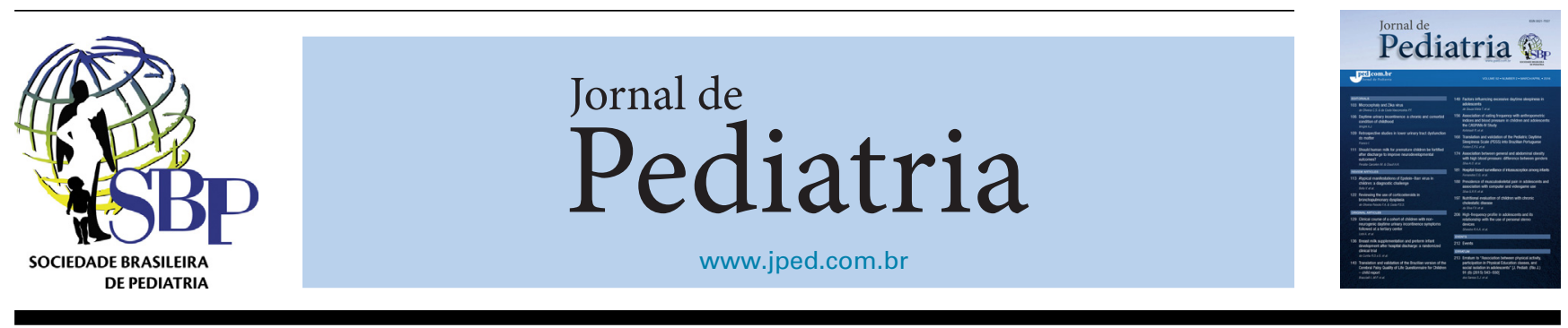

REVIEW ARTICLE

\title{
Excessive crying in infants
}

\section{Ricardo Halpern*, Renato Coelho}

Child Development Outpatient Clinic, Hospital da Criança Santo Antônio (HCSA), Santa Casa de Porto Alegre, Porto Alegre, RS, Brazil

Received 21 December 2015; accepted 14 January 2016

Available online 17 March 2016

\section{KEYWORDS}

Excessive crying;

Infant;

Circadian rhythm;

Infantile colic

\begin{abstract}
Objective: Review the literature on excessive crying in young infants, also known as infantile colic, and its effects on family dynamics, its pathophysiology, and new treatment interventions. Data source: The literature review was carried out in the Medline, PsycINFO, LILACS, SciELO, and Cochrane Library databases, using the terms "excessive crying," and "infantile colic," as well technical books and technical reports on child development, selecting the most relevant articles on the subject, with emphasis on recent literature published in the last five years.

Summary of the findings: Excessive crying is a common symptom in the first 3 months of life and leads to approximately $20 \%$ of pediatric consultations. Different prevalence rates of excessive crying have been reported, ranging from $14 \%$ to approximately $30 \%$ in infants up to 3 months of age. There is evidence linking excessive crying early in life with adaptive problems in the preschool period, as well as with early weaning, maternal anxiety and depression, attention deficit hyperactivity disorder, and other behavioral problems. Several pathophysiological mechanisms can explain these symptoms, such as circadian rhythm alterations, central nervous system immaturity, and alterations in the intestinal microbiota. Several treatment alternatives have been described, including behavioral measures, manipulation techniques, use of medication, and acupuncture, with controversial results and effectiveness.

Conclusion: Excessive crying in the early months is a prevalent symptom; the pediatrician's attention is necessary to understand and adequately manage the problem and offer support to exhausted parents. The prescription of drugs of questionable action and with potential side effects is not a recommended treatment, except in extreme situations. The effectiveness of dietary treatments and use of probiotics still require confirmation. There is incomplete evidence regarding alternative treatments such as manipulation techniques, acupuncture, and use of the herbal supplements and behavioral interventions.

( ) 2016 Sociedade Brasileira de Pediatria. Published by Elsevier Editora Ltda. This is an open access article under the CC BY-NC-ND license (http://creativecommons.org/licenses/ by-nc-nd/4.0/).
\end{abstract}

\footnotetext{
is Please cite this article as: Halpern R, Coelho R. Excessive crying in infants. J Pediatr (Rio J). 2016;92(3 Suppl 1):S40-5.

* Corresponding author.

E-mail: ricardo.halpern@gmail.com (R. Halpern).
} 


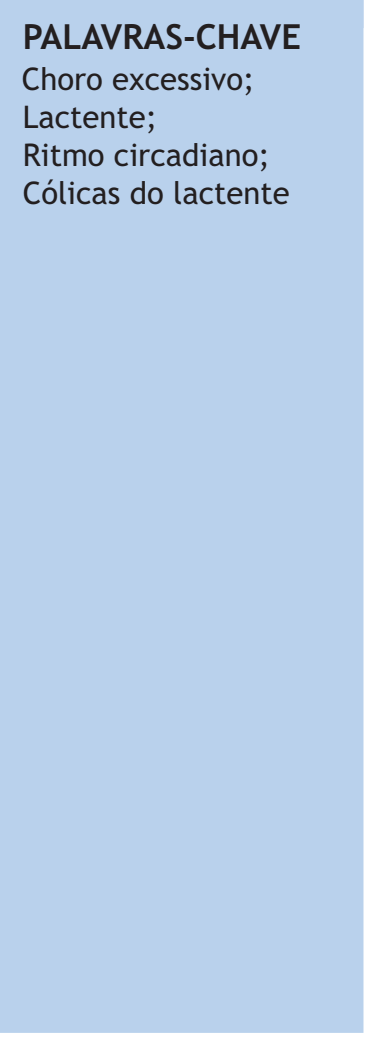

\section{Choro excessivo do lactente}

\section{Resumo}

Objetivo: Revisar a literatura sobre choro excessivo em bebês pequenos, cólicas infantis, e suas repercussões na família e a fisiopatologia e estratégias de tratamentos.

Fonte dos dados: Revisadas as principais bases de dados, Medline, PsycINFO, LILACS e SciELO e Cochrane Library utilizando "choro excessivo do lactente" e "cólicas do lactente". Foram selecionadas as publicações mais relevantes com ênfase nos últimos cinco anos.

Síntese dos dados: É um sintoma comum nos primeiros meses de vida e é motivo de cerca de $20 \%$ das consultas pediátricas. As prevalências de choro excessivo variam de 14 a $30 \%$ nestes lactentes. Existem evidências ligando o choro excessivo nos primeiros meses de vida com problemas futuros bem como ao desmame precoce, ansiedade, depressão materna, TDAH e outros problemas comportamentais. Distintos mecanismos fisiopatológicos podem explicar esse quadro clínico, como alterações no ritmo circadiano, imaturidade do SNC, e alterações na microbiota intestinal. São descritos diversas alternativas de tratamento desde medidas comportamentais, técnicas manipulativas, uso de medicação e acupuntura com resultados e eficácia controversos. Conclusão: Para o choro excessivo nos primeiros meses é necessário a atenção do pediatra para o entendimento, manejo do problema e oferecer suporte para pais em exaustão. A prescrição de drogas de efeitos duvidosos e potenciais efeitos colaterais não é terapêutica preconizada a não ser em situações extremas. A eficácia dos tratamentos dietéticos e o uso de probióticos ainda necessita de confirmação. Existem evidencias incompletas a respeito de tratamentos alternativos como técnicas manipulativas, acupuntura e uso de suplemento a base de ervas e intervenções comportamentais.

() 2016 Sociedade Brasileira de Pediatria. Publicado por Elsevier Editora Ltda. Este é um artigo Open Access sob a licença de CC BY-NC-ND (http://creativecommons.org/licenses/ by-nc-nd/4.0/).

\section{Introduction}

Crying is a common symptom in the first 3 months of life and is responsible for approximately $20 \%$ of pediatric consultations. Although in most cases this symptom is selflimited and of benign etiology, it is a source of stress and often leads parents and caregivers to exhaustion. ${ }^{1}$ Crying is part of the normal development of a baby and constitutes a form of communication with their caregivers, although nonspecific, and can be caused by different stimuli, such as hunger, manifestation of discomfort or pain, or simply the baby's need to approach the caregiver for emotional comfort and safety. Different prevalence rates of excessive crying have been reported in several studies, ranging from $14 \%$ to approximately $30 \%$ in infants up to 3 months of age. ${ }^{1,2}$ A meta-analysis performed with 22 longitudinal studies showed evidence that associates excessive crying and other regulatory difficulties (sleeping and eating) in the first months of life with adaptive problems at school age, mainly related to attention deficit hyperactivity disorder (ADHD) symptoms and associated behaviors. ${ }^{3,4}$

In a cohort study in the city of Pelotas, infants that had excessive crying in the first three months had approximately $30 \%$ more behavioral problems than those that did not have excessive crying, even after controlling for all confounding factors. ${ }^{5}$ Additionally, it is associated with early weaning, and maternal anxiety and depression. ${ }^{6-9}$

\section{Definitions and classification}

In a classic study about crying in infants, Brazelton defines excessive crying as any amount of crying that worries the parents, ${ }^{10}$ but the consensus definition by several authors are the criteria defined by Wessel, ${ }^{11}$ known as the "rule of three"' (crying spells at least three hours a day, three times a week for three consecutive weeks and lasting three months). Even with a consensus, there is no single definition of what should be considered excessive crying. ${ }^{12}$ An attempt at classification was carried out using three criteria: from newborn up to 4 months of age, infants with crying spells and irritability for three or more hours a day, three days a week and at least for one week, and no failure to thrive, i.e., without any consequences for the child's development. ${ }^{13}$ An example would be a healthy infant, aged up to 3 months, who feeds well and has a prolonged, strident crying spell, which can last up to a few hours, writhing and bending the knees and thighs over the abdomen eliminating gases; the child seems hungry, but does not calm down after being fed. It is a crying spell without apparent cause and may be a manifestation of other medical conditions, self-limited and benign.

Although it has a benign etiology, it causes parental stress, often leading parents to exhaustion without solving the problem, which, as a result, can lead parents to take dangerous measures in an attempt to calm the infant. ${ }^{14}$ In addition to the indiscriminate use of painkillers and sedative medications, there are several studies showing that 
excessive crying without quick resolution in infants is one of the causes of shaken baby syndrome. ${ }^{15,16}$

In study by Brazelton ${ }^{10}$ of typical infants, excessive crying is measured in hours/day. In this study, the mean crying time of an infant aged 2 weeks is one hour and 45 minutes, and at 12 weeks of age, the mean time is up to two hours and 45 minutes; at 12 weeks, the mean time decreases to one hour. These crying spells are more frequent in the late afternoon, with a peak occurrence at 3-6 weeks of age.

Over time, attentive caregivers begin to differentiate what motivates the infant's crying, but the perception of discomfort and suffering often confounds their interpretation, leading to an overvaluation and hindering a more thorough assessment. As a didactic characterization and classification, the crying could be divided into three categories: (1) normal/physiological; (2) excessive, secondary to discomfort or disease; and (3) without an apparent cause, where colic is included. ${ }^{17}$

\section{Colic}

Colic is a clinical manifestation, for which several attempts at explanation have been made and of whose etiology still remains unclear. ${ }^{18}$ The current understanding is that infantile colic is a variation of normality rather than a pathological entity, ${ }^{12,18}$ and it is a phenomenon that still lacks further understanding, but it is an important manifestation, through crying, that affects $20-30 \%$ of infants up to 3 months of age. ${ }^{12}$ A prospective study with ten years of follow-up showed that excessive crying caused by colic may be an early manifestation of susceptibility to recurrent abdominal pain, psychological problems, and allergies that will affect childhood. ${ }^{19}$

Among the studies on the etiology and pathophysiological mechanisms, the current and most accepted hypothesis is that excessive crying is caused due to an imbalance in the central nervous system of these infants, supported by the fact that children born with central nervous system impairment have more intense crying spells, ${ }^{18}$ as well as infants whose mothers or fathers have depression or those born premature or small for gestational age, ${ }^{20,21}$ who show an increased risk of excessive crying during the first months of life. This hypothesis is based on the fact that these groups, who naturally have greater biological risk, are also at increased risk of developmental delays, which may be related to the immaturity of the central nervous system (CNS) as well as the digestive system.

The circadian system plays an important role in the CNS, and some studies associate this function with colic and excessive crying. ${ }^{22}$ The circadian system, regulated by the hypothalamus, affects physiological activities such as sleep time, body temperature, feeding, and production of hormones such as melatonin; it matures during the first 3 months of life. Although no change in total hours of sleep has been demonstrated, infants with excessive crying show a differentiated pattern in random eye movement sleep and a fragmented sleep pattern. ${ }^{23}$ Additionally, cortisol does not increase significantly only in cases of stress, as it also shows a circadian rhythm, with an important role in the process of waking in the morning; ${ }^{22}$ in a study with control group, including infants with and without colic, the difference between them was the absence of the cortisol circadian rhythm in the group with colic. ${ }^{24}$

The evidence that supports this hypothesis is that infants with exclusive breastfeeding have fewer colic spells; it has been observed that the nocturnal breast milk has higher amounts of melatonin ${ }^{25}$ and that the infants tend to have longer and less-fragmented sleep. Likewise, there is a variation in the amount of melatonin in breast milk, which may change according to the mother's mood ${ }^{26}$ and is possibly related to stress.

Regarding nutritional intolerances, mainly the intolerance to lactose or allergy to milk, and, indirectly, the irritative substances transmitted through breast milk, several studies suggest an insignificant participation of these elements in excessive crying in healthy infants, dividing the opinion of pediatric gastroenterologists. ${ }^{18}$ When an infant has lactose intolerance or allergy to cow's milk, in addition to the crying the infant will also show other clinical manifestations, and thus the criteria for colic will no longer be valid, as these infants are not healthy. Similarly, there is no consensus in cases of gastroesophageal reflux and the use of proton-pump inhibitors to reduce gastric juice, as a procedure to relieve crying spells in infants with this type of problem. ${ }^{27}$ In recent years, some studies focused on the association of intestinal microbiota, altered intestinal motility, and the increased production of gases, causing abdominal pain and resulting in crying. ${ }^{28-31}$ After birth, there is a gradual increase in the diversity of the infants' intestinal flora, but in those with excessive crying spells, considering the colic criteria, the diversity was lower and they had a reduced amount of bifidobacteria and lactobacilli. ${ }^{28}$ The colonization of gas-producing coliform bacteria was significantly higher in children with colic spells in a study of exclusively breastfed infants, with a predominance of Escherichia coli. ${ }^{29}$ There is indication that there may be an intestinal inflammatory reaction, in addition to lower microbiota diversity in infants with colic spells. ${ }^{31}$

Some newborns, while still in the nursery, can be perceived as likely candidates to have excessive crying spells, with increased chances of meeting the criteria for colic. These infants are sensitive, with increased irritability, prone to intense reactions and less adaptable, who take longer to calm down with the usual measures of being held and cuddled. This situation characterizes the influence of the infant's temperament, which is defined as a set of characteristics related to the type of response to stimuli, their adaptive capacity (ability to calm down in stressful situations), and activity level. ${ }^{32,33}$ When this infant, characterized by having a difficult temper, finds a non-favorable environment, with tense and insecure caregivers who deal inadequately with the infant, the excessive crying will be the most common manifestation of discomfort. ${ }^{34,35}$ Studies have been performed to verify whether the difficult temper seen in adults, demonstrated by structural changes in their brains, may be predictive when observed in infants with hyper-reactive temperament. ${ }^{36}$

Even in infants without this a difficult temper, the environmental factors that cause family disruption, such as psychosocial problems and domestic violence, may be related to excessive crying. The infant acts as a signaler of what is happening with their caregivers, mainly the mother, markedly interfering in the mother-infant bond, as can be 
better observed in the cases of postnatal depression. ${ }^{20,37}$ In a prospective study, it was shown that stress during pregnancy was strongly related to excessive crying spells in infants during the first 6 months of life. ${ }^{38}$

\section{Diagnosis}

As in any clinical research, the assessment begins with a history of symptoms described by the family, providing details such as frequency, intensity, time of occurrence, and duration of crying. The complaint of excessive crying demands from the pediatrician a careful assessment of the infant's behavior and reactions, and the interaction of parents and caregivers. It also demands searching, whenever possible, for a triggering event or situation in the infant's routine, even if not directly connected to it, such as a family stress situation (psychosocial factors such as unemployment, marital crises, mourning). The way parents arrive and describe the complaint, associated with the description of how they hold and receive their babies, as well as the strategies used to calm them, are an important source of observation and can be used therapeutically during the consultation. ${ }^{39}$ The history and the motivation of the pregnancy and parents facilitate the understanding, representation, and the role of the infant in the family.

During the physical examination of a small infant with excessive crying that meets the criteria for colic, it is not common to find semiological alterations, but it is indispensable to perform a complete examination as part of the assessment and as a management strategy, in order to ensure to parents that the infant does not have any associated pathology. This procedure ensures the possibility of using clinical reasoning to search, whenever evident, for a differential diagnosis among those listed in Table 1. Additional tests are not part of the research protocol unless the history and physical examination suggests some possible cause. ${ }^{40}$

\section{Clinical management}

For clinical management, it is crucial to understand the complexity of symptoms and the possible causes, which in most cases are not explicit. As in other behavioral and development manifestations, the concept of cumulative risk effect can be applied to excessive infant crying. ${ }^{41}$ Most of the time, there is a set of factors with little individual weight, but which together cause the clinical manifestation. At first, it is necessary to recognize the problem, giving support and reassurance to the family, providing information about the benign condition and its natural history, in which $95 \%$ of cases are self-limited and only $5 \%$ have primary causes. Information about the normal pattern of crying and the infant's self-regulatory mechanisms help to understand the problem, as well as the necessary preventive measures against shaken baby syndrome and maltreatment. ${ }^{18}$ Often parents already show signs of fatigue and a few are exhausted. In extreme situations, the use of nocturnal emergencies services is frequent and, often, unnecessary therapeutic measures are taken.

The necessary support to the family begins at the consultation and with the pediatrician's availability to help them. The pediatrician must be attentive and interested in
Table 1 The most common causes of excessive crying in young infants.

\begin{tabular}{|c|c|}
\hline Colic & $\begin{array}{l}\text { No apparent cause, healthy } \\
\text { infant, gaining weight, "rule } \\
\text { of threes" }\end{array}$ \\
\hline Infections & $\begin{array}{l}\text { Otitis media; urinary infection; } \\
\text { meningitis }\end{array}$ \\
\hline Gastrointestinal & $\begin{array}{l}\text { Gastroesophageal reflux; reflux } \\
\text { esophagitis; constipation; } \\
\text { intestinal intussusception, } \\
\text { lactose intolerance, or allergy } \\
\text { to cow's milk }\end{array}$ \\
\hline Trauma & $\begin{array}{l}\text { Corneal abrasion; foreign body } \\
\text { in the eye, "toe-tourniquet" } \\
\text { syndrome (strangulation of } \\
\text { digits) }\end{array}$ \\
\hline Behavioral/interactional & $\begin{array}{l}\text { Excessive stimulation, lack of } \\
\text { routine, bonding disorder }\end{array}$ \\
\hline Drug reactions & $\begin{array}{l}\text { Reactions to vaccines; drugs } \\
\text { used during pregnancy } \\
\text { (narcotics) }\end{array}$ \\
\hline Violence/abuse & $\begin{array}{l}\text { Long bone fractures; eye } \\
\text { hemorrhage; intracranial } \\
\text { hemorrhage }\end{array}$ \\
\hline $\begin{array}{l}\text { Hematological/ } \\
\text { cardiovascular }\end{array}$ & $\begin{array}{l}\text { Hemolytic crisis - sickle-cell } \\
\text { anemia; tachyarrhythmia; } \\
\text { congestive heart failure }\end{array}$ \\
\hline
\end{tabular}

Source: Modified and adapted from Grover. ${ }^{17}$

helping, and perform an adequate clinical assessment in order to establish a secure baseline to confirm that the infant is healthy. The positive reinforcement strategy is most effective when parents are helped by the pediatrician to find the solutions together, rather than only the transfer of information to them. ${ }^{18}$

According to the Wessel criteria for the diagnosis, the use of the rule of threes in the management is also useful: (1) infantile colic is not a disease; (2) nothing will happen to the infant because of the pain (dispel myths); (3) colic passes on its own and "it is a problem that the baby will learn to solve" (presenting the natural history of this kind of problem), relieving parents from the responsibility to "solve" the crying. ${ }^{42}$ It is an educational process for the parents to learn to solve crises, clarifying the meanings of the infant's crying, dispelling myths, relieving feelings of guilt and the need to share the burden, while the other rests.

It is essential to avoid the simplification of the phenomenon and the consequent prescription of controversial drugs that have adverse effects, as well as exposing the infant to unnecessary tests and procedures. It is also important to discourage changes in the infant's feeding schemes, such as from breast milk to infant formula, as well as from the usual formula to different brands or sources, such as soy milk or hydrolyzed formulas, without a justified clinical basis. ${ }^{18}$ Calming the child in one of the parent's arms, or in the prone position, with a warm cloth or using hot water bottles touching the child's abdomen and abdominal massage, are procedures that show some evidence of crying improvement. Symptom improvement with these techniques may be associated with a sense of protection, thereby improving 
mother-infant bonding, sleep patterns, and stress hormone levels; ${ }^{43}$ nevertheless, placing the infant in the prone position in the crib should be discouraged, even if this position improves the crying spells. ${ }^{18}$ The use of a pacifier can be occasionally allowed if it calms the infant; the relevant guidelines for using this resource can be left for later. ${ }^{42}$

Some approaches have shown some evidence of benefit, such as wrapping the infant, which has been shown to be more efficient the younger the baby is, up to 8 weeks of age, when compared to the group that was not wrapped. Historical reports show the use of this procedure in the past; the main effect is increased sleep duration and decreased motor activity. ${ }^{44}$ Similarly, the use of sleep hygiene and the establishment of a routine, organizing the infant's and the parents' day, proved to be effective in reducing crying by $42 \% .{ }^{45}$ The use of teas, such as fennel, licorice, chamomile, and peppermint, were part of a systematic review, and some encouraging results were shown using fennel versus placebo $^{46}$; since they do not have side effects, they could be used as a therapeutic aid. ${ }^{18}$

The prescription of drugs is controversial and their use should be discouraged due to the lack of evidence of benefits, but in rare cases, such as in a family crisis, with very high anxiety levels, sleep deprivation, without a family support network, and with the infant at risk of suffering the consequences of family dysfunction, drugs can be temporarily used. The most often recommended are phenobarbital at a dose of $10 \mathrm{mg}$ three times/day or diphenhydramine, $6 \mathrm{mg}$, two to three times/day, both for one week, so that the initial approach steps can be resumed. ${ }^{12}$ The use of simethicone is now well-accepted in clinical practice, more frequently through self-medication, but it shows no evidence of benefit, ${ }^{47}$ and its effect could be a consequence of the calming effect of its sweet taste. ${ }^{46}$

It is noteworthy that the isolated use of drugs greatly reduces the effect of a more comprehensive and systemic approach to solving the problem. ${ }^{12}$

The use of probiotics is part of several studies and is increasing as a promise of improvement in colic symptoms, but the evidence of its effectiveness and the results are controversial. ${ }^{48}$ In a recent meta-analysis there was an improvement in crying and treatment effectiveness, but only after two to three weeks and together with the natural history of colic improvement. ${ }^{49}$ In another systematic review and meta-analysis study, the improvement occurred only in the group of infants that was breastfed and the study concluded that there is little evidence to recommend the use of probiotics in the treatment of infants with colic. ${ }^{30}$

Some alternative therapies have been proposed for the treatment of colic and excessive crying, including chiropractic and cranial manipulation. A systematic review in the Cochrane database, although showing in some studies a reduction in colic symptoms and crying using these techniques, does not allow the clinical use of the outcomes due to potential biases in the studies..$^{50}$

Another proposed treatment is acupuncture, but its results are also controversial, and further clinical trials are recommended to elucidate the effects of this form of therapy for excessive crying and infantile colic. ${ }^{51}$

Crying as a prevalent symptom is usually a form of communication in young and healthy infants. The pediatrician's careful assessment in separating symptoms that can have another meaning besides crying is essential for the emotional health of the infant. It is increasingly more evident that the first years, whether healthy or not, will define the child's development and often their behavior in adulthood. Therefore, building a therapeutic cooperation through empathy will allow the pediatrician to be an active observer and effectively elucidate the issues related to excessive infant crying. ${ }^{41,52}$

\section{Conflicts of interest}

The authors declare no conflicts of interest.

\section{References}

1. Kim JS. Excessive crying: behavioral and emotional regulation disorder in infancy. Korean J Pediatr. 2011;54:229-33.

2. Reijneveld SA, Brugman E, Hirasing RA. Excessive infant crying: the impact of varying definitions. Pediatrics. 2001;108:893-7.

3. Hemmi MH, Wolke D, Schneider S. Associations between problems with crying, sleeping and/or feeding in infancy and long-term behavioural outcomes in childhood: a meta-analysis. Arch Dis Child. 2011;96:622-9.

4. Schmid G, Wolke D. Preschool regulatory problems and attention-deficit/hyperactivity and cognitive deficits at school age in children born at risk: different phenotypes of dysregulation? Early Hum Dev. 2014;90:399-405.

5. Santos IS, Matijasevich A, Capilheira MF, Anselmi L, Barros FC. Excessive crying at 3 months of age and behavioural problems at 4 years age: a prospective cohort study. J Epidemiol Community Health. 2015;69:654-9.

6. Barros FC, Halpern R, Victora CG, Teixeira AMB, Béria JU. Promoção da amamentação em localidade urbana da região sul do Brasil: estudo de intervenção randomizado. Rev Saude Publica. 1994;28:277-83.

7. Hiscock H, Cook F, Bayer J, Le HN, Mensah F, Cann W, et al. Preventing early infant sleep and crying problems and postnatal depression: a randomized trial. Pediatrics. 2014;133:e346-54.

8. Vik T, Grote V, Escribano J, Socha J, Verduci E, Fritsch M, et al. Infantile colic, prolonged crying and maternal postnatal depression. Acta Paediatr. 2009;98:1344-8.

9. Radesky JS, Zuckerman B, Silverstein M, Rivara FP, Barr M, Taylor JA, et al. Inconsolable infant crying and maternal postpartum depressive symptoms. Pediatrics. 2013;131:e1857-64.

10. Brazelton TB. Crying in infancy. Pediatrics. 1962;29:579-88.

11. Wessel MA, Cobb JC, Jackson EB, Harris GS, Detwiler AC. Paroxysmal fussing in infancy, sometimes called colic. Pediatrics. 1954;14:421-35.

12. Carey WB. Colic Prolonged or excessive crying in young infants. In: Carey WB, editor. Developmental-behavioral pediatrics. 4th ed. Philadelphia: Saunders Elsevier; 2009. p. 557-62.

13. Hyman PE, Milla PJ, Benninga MA, Davidson GP, Fleisher DF, Taminiau J. Childhood functional gastrointestinal disorders: neonate/toddler. Gastroenterology. 2006;130:1519-26.

14. Reijneveld SA, van der Wal MF, Brugman E, Sing RAH, Verloove-Vanhorick SP. Infant crying and abuse. Lancet. 2004;364:1340-2.

15. Duhaime AC, Christian CW, Rorke LB, Zimmerman RA. Nonaccidental head injury in infants - the shaken-baby syndrome. $\mathrm{N}$ Engl J Med. 1998;338:1822-9.

16. Fujiwara T, Barr RG, Brant R, Barr M. Infant distress at five weeks of age and caregiver frustration. J Pediatr. 2011;159:425-30.e2.

17. Grover G. Crying and colic. In: Berkowitz CD, editor. Pediatrics: a primary care approach. 1st ed. Philadelphia (PA): Saunders Company; 1996. p. 102-4. 
18. Akhnikh S, Engelberts AC, van Sleuwen BE, L'Hoir MP, Benninga MA. The excessively crying infant: etiology and treatment. Pediatr Ann. 2014;43:e69-75.

19. Savino F, Castagno E, Bretto R, Brondello C, Palumeri E, Oggero R. A prospective 10-year study on children who had severe infantile colic. Acta Paediatr Suppl. 2005;94:129-32.

20. van den Berg MP, van der Ende J, Crijnen AA, Jaddoe VW, Moll HA, Mackenbach JP, et al. Paternal depressive symptoms during pregnancy are related to excessive infant crying. Pediatrics. 2009;124:e96-103.

21. Milidou I, Søndergaard C, Jensen MS, Olsen J, Henriksen TB. Gestational age, small for gestational age, and infantile colic. Paediatr Perinat Epidemiol. 2014;28:138-45.

22. Shamir R, James-Roberts IS, Di Lorenzo C, Burns AJ, Thapar $N$, Indrio $F$, et al. Infant crying, colic, and gastrointestinal discomfort in early childhood. J Pediatr Gastroenterol Nutr. 2013;57:S1-45.

23. Brand S, Furlano R, Sidler M, Schulz J, Holsboer-Trachsler E. "Oh, baby, please don't cry!": in infants suffering from infantile colic hypothalamic-pituitary-adrenocortical axis activity is related to poor sleep and increased crying intensity. Neuropsychobiology. 2011;64:15-23.

24. White BP, Gunnar MR, Larson MC, Donzella B, Barr RG. Behavioral and physiological responsivity, sleep, and patterns of daily cortisol production in infants with and without colic. Child Dev. 2000;71:862-77.

25. Cohen Engler A, Hadash A, Shehadeh N, Pillar G. Breastfeeding may improve nocturnal sleep and reduce infantile colic: potential role of breast milk melatonin. Eur J Pediatr. 2012;171:729-32.

26. Kimata H. Laughter elevates the levels of breast-milk melatonin. J Psychosom Res. 2007;62:699-702.

27. van der Pol RJ, Smits MJ, van Wijk MP, Omari TI, Tabbers MM, Benninga MA. Efficacy of proton-pump inhibitors in children with gastroesophageal reflux disease: a systematic review. Pediatrics. 2011;127:925-35.

28. de Weerth C, Fuentes S, Puylaert P, de Vos WM. Intestinal microbiota of infants with colic: development and specific signatures. Pediatrics. 2013;131:e550-8.

29. Savino F, Cordisco L, Tarasco V, Calabrese R, Palumeri E, Matteuzzi D. Molecular identification of coliform bacteria from colicky breastfed infants. Acta Paediatr. 2009;98:1582-8.

30. Sung V, Collett S, de Gooyer T, Hiscock H, Tang M, Wake M. Probiotics to prevent or treat excessive infant crying. JAMA Pediatr. 2013; 167:1150-7.

31. Rhoads JM, Fatheree NY, Norori J, Liu Y, Lucke JF, Tyson JE, et al. Altered fecal microflora and increased fecal calprotectin in infants with colic. J Pediatr. 2009;155:823-8.e1.

32. Buss AH, Plomin R. Temperament: early developing personality traits. 1st ed. Hillsdale (NJ): Lawrence Erlbaum Associates; 1984.

33. Goldsmith HH, Alansky JA. Maternal and infant temperamental predictors of attachment: a meta-analytic review. J Consult Clin Psychol. 1987;55:805-16.

34. Douglas $P$, Hill P. Managing infants who cry excessively in the first few months of life. BMJ. 2011;343:d7772.

35. Yalçın SS, Örün E, Mutlu B, Madendağ Y, Sinici I, Dursun A, et al. Why are they having infant colic? A nested case-control study. Paediatr Perinat Epidemiol. 2010;24:584-96.

36. Schwartz CE, Kunwar PS, Greve DN, Moran LR, Viner JC, Covino JM, et al. Structural differences in adult orbital and ventromedial prefrontal cortex predicted by infant temperament at 4 months of age. Arch Gen Psychiatry. 2010;67:78-84.

37. Talge NM, Neal C, Glover V. Early stress, translational research and prevention science network: fetal and neonatal experience on child and adolescent mental health. Antenatal maternal stress and long-term effects on child neurodevelopment: how and why? J Child Psychol Psychiatry. 2007;48:245-61.

38. Wurmser H, Rieger M, Domogalla C, Kahnt A, Buchwald J, Kowatsch $M$, et al. Association between life stress during pregnancy and infant crying in the first six months postpartum: a prospective longitudinal study. Early Hum Dev. 2006;82:341-9.

39. Célia SAH, Halpern R. A consulta terapêutica: a importância da intervenção precoce na primeira infância. In: Halpern R, editor. Manual de pediatria do desenvolvimento e comportamento. Barueri (SP): Manole; 2015. p. 73-82.

40. Freedman SB, Al-Harthy N, Thull-Freedman J. The crying infant: diagnostic testing and frequency of serious underlying disease. Pediatrics. 2009;123:841-8.

41. Halpern R. A criança vulnerável: o papel dos fatores de risco e proteção na determinação do desenvolvimento da criança. In: Halpern R, editor. Manual de pediatria do desenvolvimento e comportamento. Barueri (SP): Manole; 2015. p. 59-71.

42. Coelho R. Choro excessivo de um lactente pequeno - cólicas. In: Halpern R, editor. Manual de Pediatria do Desenvolvimento e Comportamento. Barueri (SP): Manole; 2015. p. 245-53.

43. Underdown A, Barlow J, Chung V, Stewart Brown S. Massage intervention for promoting mental and physical health in infants aged under six months. Cochrane Database Syst Rev. 2006;18:CD005038.

44. Van Sleuwen BE, L'hoir MP, Engelberts AC, Busschers WB, Westers $\mathrm{P}$, Blom MA, et al. Comparison of behavior modification with and without swaddling as interventions for excessive crying. J Pediatr. 2006;149:512-22.

45. Blom MA, van Sleuwen BE, de Vries H, Engelberts AC, L'Hoir MP. Health care interventions for excessive crying in infants: regularity with and without swaddling. J Child Health Care. 2009;13:161-76.

46. Perry R, Hunt K, Ernst E. Nutritional supplements and other complementary medicines for infantile colic: a systematic review. Pediatrics. 2011;127:720-33.

47. Danielsson B, Hwang CP. Treatment of infantile colic with surface active substance (simethicone). Acta Paediatr. 1985; 74:446-50.

48. Cruchet S, Furnes R, Maruy A, Hebel E, Palacios J, Medina $\mathrm{F}$, et al. The use of probiotics in pediatric gastroenterology: a review of the literature and recommendations by latinAmerican experts. Pediatr Drugs. 2015;17:199-216.

49. Xu M, Wang J, Wang N, Sun F, Wang L, Liu X-H. The efficacy and safety of the probiotic bacterium lactobacillus reuteri DSM 17938 for infantile colic: a meta-analysis of randomized controlled trials. Lionetti V, editor. PLOS ONE. Public Library of Science; 2015;10(10):e0141445.

50. Dobson D, Lucassen PL, Miller JJ, Vlieger AM, Prescott P, Lewith G. Manipulative therapies for infantile colic. Cochrane Database Syst Rev. 2012;12:CD004796.

51. Savino F, Ceratto S, De Marco A, Cordero di Montezemolo L. Looking for new treatments of infantile colic. Ital J Pediatr. 2014:40:53.

52. Assumpção FB Jr. Sinais precoces do sofrimento psíquico. In: Halpern R, editor. Manual de pediatria do desenvolvimento e comportamento. Barueri (SP): Manole; 2015. p. 363-71. 